\title{
THE GEOCHEMISTRY OF BANDED IRON FORMATIONS IN THE SUKUMALAND GREENSTONE BELT OF GEITA, NORTHERN TANZANIA: EVIDENCE FOR MIXING OF HYDROTHERMAL AND CLASTIC SOURCES OF THE CHEMICAL ELEMENTS
}

\author{
MAH Maboko \\ Department of Geology, University of Dar es Salaam \\ P.O. Box 35052, Dar es Salaam, Tanzania
}

\begin{abstract}
Major and trace element compositions of samples of Banded Iron Formations (BIF) from the Neoarchaean Sukumaland. Greenstone Belt of Geita in northern Tanzania reveal that the BIF precipitated from hydrothermal solutions. Fe-Ti-Al-Mn systematics suggest that the hydrothermal deposits have been contaminated, by up to $20 \%$ by weight, with detrital material having a composition similar to modern deep-sea pelagic clays. $\mathrm{SiO}_{2}$ and $\mathrm{Fe}_{2} \mathrm{O}_{3}$ contents are 48.2 to $88.5 \%$ and 8.9 to $49.1 \%$ respectively. $\mathrm{Al}_{2} \mathrm{O}_{3}$ contents lie between 0.33 and $2.1 \%$ and show no correlation with either $\mathrm{Fe}_{2} \mathrm{O}_{3}$ or $\mathrm{SiO}_{2} . \mathrm{Al}_{2} \mathrm{O}_{3}$ is, however, positively correlated with Ti, Ga, $\mathrm{H}, \mathrm{Rb}, \mathrm{Th}, \mathrm{Zr}$ and Sr but not with $\mathrm{CaO}$, the alkalies and the total Rare Earth Elements (REE). The other major element oxides are generally present in negligible amounts. The samples are characterised by mean $\mathrm{Zr} / \mathrm{Hf}$ and ${ }^{144} \mathrm{Sm} /{ }^{143} \mathrm{Nd}$ ratios of $48 \pm 5$ $(2 S E$ ) and $0.10 \pm 0.01$ (2SE) respectively, similar to mean upper continental crustal values. Shale-normalised REE patterns are nearly flat, except for small positive Eu and very slight negative Ce anomalies and reveal that, compared to average upper crust, the abundances of the REE in the BIF are up to an order of magnitude lower. Chondrite-normalised patterns are characterised by light $(L)$ REE enrichment, flat to slightly depleted heavy (H) REE, slightly positive Eu anomalies and very small negative Ce anomalies. The HREEdepleted patterns are similar to patterns derived from granitedominated upper continental crust and indicate that the bulk of the REE in the Geita BIF can not have been derived from a mixture of Neoarchaean sea water and bottom hydrothermal solutions. The trace element data, and the REE in particular, indicate that, despite their relatively low proportions, granitic
\end{abstract}


detritus probably derived from contemporaneous felsic flows and pyroclastics are the cause of the dominant trace element geochemical signature of the BIF.

\section{INTRODUCTION}

Banded Iron Formations (BIF) are marine chemical precipitates that form an integral part of the preserved Archaean to Proterozoic sedimentary succession in different parts of the world. In general, two main types of BIF can be distinguished. The Superior-type BIF, which are dominant in the Proterozoic, are characterised by shallow continental shelf sedimentary associations whereas Algoma-type BIF occur in close association with mafic and felsic volcanic rocks, graywackes and carbonaceous shales in small sedimentary basins in many Mesoarchaean greenstone belts (Klemm 2000).

The origin of the Fe and $\mathrm{Si}$ that constitute the bulk of the BIF remains contentious. Some researchers contend that the $\mathrm{Fe}$ and $\mathrm{Si}$ are of terrigenous origin, having been derived from land by weathering processes (James 1954, Lepp \& Goldich 1973, Garrels 1987, Holland 1984, Halbich et al. 1993). Two variants of the terrigenous origin are generally advocated. The first variant assumes that these elements are carried directly into the oceans as dissolved matter in river water (James 1954). The second variant assumes that the elements are leached from the suspended load of rivers after deposition in the deeper, more reducing part of the ocean (Holland 1984). Other workers, however, favour a volcanogenic hydrothermal origin for most of the elements in BIF (Goodwin 1962, Jacobsen \& Pimentel-Klose 1988, Barley et al. 1997). The hydrothermal origin, an analogue of which are the hydrothermal systems operating along modern mid-ocean ridges, is particularly favoured for the Algoma - type BIF because of their strong association with volcanic and/or volcanoclastics rocks (Jacobsen \& Pimentel-Klose 1988).

Regardless of the ultimate source of the constituent chemical elements, detritus-poor BIF are useful indicators of the temporal evolution of sea water chemistry and the physico-chemical conditions that have influenced its composition from Archaean to Proterozoic times. In particular, REE geochemistry has been used to put some constraints on the various geochemical fluxes that have influenced seawater chemistry in the past (Jacobsen \& Pimentel-Klose 1988, Derry \& Jacobsen 1990, Bau \& Moller 1993). This in turn has allowed researchers to infer the physical-chemical processes that had controlled marine chemistry during Precambrian time (Derry \& Jacobsen 1990, Bau \& Moller 1993).

The Neoarchaean Sukumaland Greenstone Belt (Borg 1992, Borg \& Shackleton 1997) of northern Tanzania contains a well developed sequence of typical Algoma-type BIF that occur in close association with metabasalts, carbonaceous shales, felsic flows and pyroclastics. This paper presents the 
first ever-published geochemical data on samples of BIF from the Sukumaland Greenstone Belt in the northern part of the Tanzania craton (Fig. 1). Because of problems with getting easily accessible fresh exposures sampling was restricted to a relatively small area surrounding the old Geita Mine were unaltered samples could be obtained from mine addits, quarries, artisanal miners' pits and road cuts. The data are used to place some constraints on the sources contributing to the major and trace element geochemical budget of the late Archaean sea from which the BIF were deposited. The term iron formation as used in this paper includes samples with Fe concentrations below the $15 \%$ lower limit proposed by James (1954).

\section{GEOLOGICAL SETTING}

The Sukumaland Greenstone Belt consists of two intermittently exposed arcs of metavolcanic and metasedimentary rocks which are cored and flanked by granitoids and gneisses in the area south of Lake Victoria (Fig. 1). In terms of the local stratigraphy, rocks of the Sukumaland Greenstone Belt belong to the Nyanzian Supergroup (Grantham et al. 1945). The Nyanzian has been subdivided into a Lower part consisting predominantly of mafic metavolcanics and an Upper part consisting of chemical metasediments, including chert and BIF, felsic tuffs and flows, agglomerates and graphitic shales (Barth 1990). The Upper Nyanzian is uncomformably overlain by coarse clastic metasediments of the Kavirondian Group (Barth 1990).

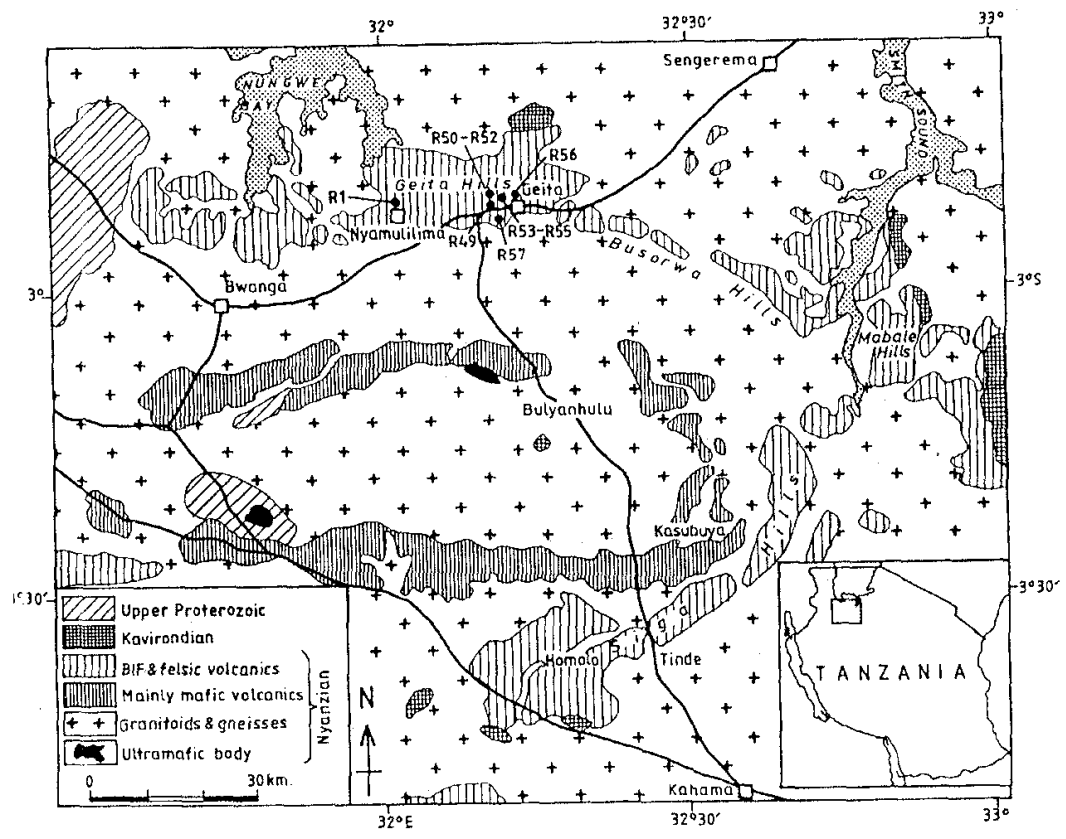

Fig. 1: Geological sketch map of the Sukumaland Greenstone Belt showing sampling localities (modified from Borg and Krogh 1999). Sampling localities are indicated by dots and numbers. 
The geological setting and lithostratigraphical subdivisions of the Sukumaland Greenstone Belt has been reviewed by Barth (1990), Borg (1992) and Borg and Shackleton (1997). These workers demonstrated that the inner arc of the Sukumaland Greenstone Belt is representative of the Lower Nyanzian whereas the outer arc, from where the samples studied herein were obtained, represents the Upper Nyanzian (Fig. 1). Walraven et al. (1994) described the BIF at Geita as belonging to the oxide facies and recognised three distinct lithofacies: a basal magnetite-haematite-chert lithofacies consisting of micro- and mesobanded magnetite-haematite and chert with $\mathrm{Fe}-\mathrm{Si}$ oxide ratios ranging from $\sim 4: 1$ at the base to $\sim 1: 3$ at the top. This lithofacies grades into an overlying banded chert lithofacies with rare mafic to intermediate tuffaceous interlayers separating the two units locally. The chert lithofacies consists of banded chert interbedded with up to $50 \mathrm{~cm}$ thick layers of white and red felsic tuffs. Only minor magnetite-rich layers or laminae occur in the chert beds. The upper most lithofacies is a transitional unit in which chemical and pyroclastic metasediments alternate. The tuff layers become more abundant and thicker towards the top of the unit.

Drilling at Nyamulilima Hill (Fig. 1) has established a local stratigraphy consisting of an upper unit of felsic tuff underlain by BIF (Manya pers. comm.). The BIF, which attains a maximum thickness of $\sim 70 \mathrm{~m}$, overlies graphitic shales consisting of coarse nodules of pyrite. The BIF forms prominent crests and ridges overlying the more easily weathered shales and pyroclastics and consists of rhythmically alternating fine bands of Fe-oxide and metachert metamorphosed into the greenschist facies. The metachert layers consist of a fine-grained granoblastic mosaic of quartz interspersed with varying proportions of $\mathrm{Fe}$ oxide whereas the oxide layers consists of a mixture of magnetite and haematite with no silicate minerals. The presence of oxide even in the nominally chert layers and the absence of quartz in the haematite-magnetite layers suggest that the rhythmic banding represents repeated cycles of Si deposition superimposed on a more or less constant flux of Fe oxide deposition. Carbonates and sulphides are generally absent except in a few samples where they occur as secondary minerals mostly in cross cutting veins. Massive sulphide-rich layers, up to $4 \mathrm{~m}$ thick and thin sulphide rich tuffaceous horizons are, however, locally interbedded with the BIF. Observations in drill cores reveal the presence in the massive sulphide layers of BIF fragments, lapilli and detrital pyrite cores, often overgrown with secondary pyrite, suggesting a pyroclastic origin for the layers. The BIF beds show tight isoclinal folding, very steep $\left(\geq 70^{\circ}\right)$ dips and along strike orientations, which are controlled by the local geometrical pattern of the folding.

The deposition age of the BIF is constrained by a zircon U-Pb age of $2699 \pm$ 9 Ma reported by Borg and Krogh (1999) from a porphyritic trachyandesite flow intercalated with BIF at the Geita mine. 


\section{Analytical Methods}

Ten BIF samples collected from the area around Geita (see Fig. 1 for sampling localities), were analysed for major and trace elements at the ACME Analytical Laboratories in Vancouver, Canada. Aliquots of the pulverised samples, mixed with $\mathrm{LiBO}_{3}$ flux, were melted prior to acid digestion. The major elements, were analysed using Inductively Coupled Plasma-Optical Emmission Spectrometry (ICP-OES) whereas the trace elements were determined using Inductively Coupled Plasma-Mass Spectrometry (ICP-MS). The analytical reproducibility as determined from duplicate analyses is better than $4 \%$ and typically $\sim 2.5 \%$ for trace elements and better than $0.2 \%$ for major elements. The accuracy of the ICP-MS measurements as calibrated against standard samples was better than $2 \%$.

\section{RESULTS}

The analytical data for the BIF samples are presented in Table 1. As expected from the petrography, the BIF are almost pure $\mathrm{SiO}_{2}-\mathrm{Fe}_{2} \mathrm{O}_{3}$ (all Fe expressed as $\left.\mathrm{Fe}^{3+}\right)$ mixtures with $\left(\mathrm{SiO}_{2}+\mathrm{Fe}_{2} \mathrm{O}_{3}\right)$ ranging from 92.9 to $98.9 \%$. $\mathrm{SiO}_{2}$ and $\mathrm{Fe}_{2} \mathrm{O}_{3}$ contents are 48.2 to $88.5 \%$ and 8.9 to $49.1 \%$ respectively. $\mathrm{Al}_{2} \mathrm{O}_{3}$ contents lie between 0.33 and $2.1 \%$ and show no correlation with either $\mathrm{Fe}_{2} \mathrm{O}_{3}$ or $\mathrm{SiO}_{2} . \mathrm{Al}_{2} \mathrm{O}_{3}$ is, however, positively correlated with $\mathrm{Ti}, \mathrm{Ga}, \mathrm{Hf}, \mathrm{Rb}, \mathrm{Th}, \mathrm{Zr}$ and $\mathrm{Sr}$ but not with $\mathrm{CaO}$, the alkalies and the total REE. The lack of correlation of $\mathrm{Al}_{2} \mathrm{O}_{3}$ with $\mathrm{CaO}$ and the alkalies suggests little input of detrital feldspar in the BIF. The other major element oxides are generally present in negligible amounts except in sample R-51 which contains $0.9 \%$ and $1.9 \%$ of $\mathrm{MgO}$ and $\mathrm{CaO}$ respectively (Table 1). In the latter sample, the $\mathrm{CaO}$ and $\mathrm{MgO}$ most likely reside in carbonate, which is present as a minor phase in the mode.

\section{Table 1: Major (in oxide weight \%) and trace element (in ppm)} composition of the Geita Banded Iron Formations

\begin{tabular}{|c|c|c|c|c|c|c|c|c|c|c|c|}
\hline $\begin{array}{l}\text { Oxide/ } \\
\text { Element }\end{array}$ & RI & R49 & R50 & R51 & $\mathrm{R} .52$ & R53 & R54 & R55 & R56 & $\mathrm{R} 56^{*}$ & R57 MEAN \\
\hline $\mathrm{SiO}_{2}$ & 88.52 & 63.55 & 65.11 & 62.23 & 81.52 & 67.07 & 48.79 & 59.41 & 80.88 & 80.76 & 48.2367 .82 \\
\hline $\mathrm{Al}_{2} \mathrm{O}_{3}$ & 1.19 & 1.42 & 2.1 & 1.79 & 0.9 & 1.24 & 0.89 & 1.1 & 0.34 & 0.33 & 0.82 \\
\hline $\mathrm{Fe}_{2} \mathrm{O}_{3}$ tot & 8.91 & 32.85 & 30.82 & 30.71 & 16.87 & 30.35 & 49.08 & 36.5 & 17.94 & 18.11 & 48.7529 .17 \\
\hline $\mathrm{MnO}$ & 0.01 & 0.02 & 0.01 & 0.05 & 0.01 & 0.01 & 0.01 & 0.01 & 0.01 & 0.01 & 0.01 \\
\hline $\mathrm{MgO}$ & 0.13 & 0.04 & $<0.01$ & 0.92 & $<0.01$ & $<0.01$ & $<0.01$ & $<0.01$ & $<0.01$ & $<0.01$ & $<0.01$ \\
\hline $\mathrm{CaO}$ & 0.07 & 0.09 & 0.03 & 1.9 & 0.07 & 0.03 & 0.03 & 0.02 & 0.05 & 0.05 & 0.09 \\
\hline $\mathrm{Na}_{2} \mathrm{O}$ & 0.02 & $<0.01$ & $<0.01$ & 0.37 & $<0.01$ & $<0.01$ & $<0.01$ & $<0.01$ & $<0.01$ & $<0.01$ & $<0.01$ \\
\hline $\mathrm{K}_{2} \mathrm{O}$ & 0.21 & 0.39 & $<0.04$ & 0.96 & $<0.04$ & $<0.04$ & $<0.04$ & $<0.04$ & $<0.04$ & $<0.04$ & 0.13 \\
\hline $\mathrm{TiO}_{2}$ & 0.02 & 0.05 & 0.08 & 0.06 & 0.02 & 0.03 & 0.03 & 0.04 & 0.01 & 0.01 & 0.02 \\
\hline $\mathrm{P}_{2} \mathrm{O}_{5}$ & 0.05 & 0.11 & 0.18 & 0.15 & 0.02 & 0.06 & 0.1 & 0.2 & 0.04 & 0.11 & 0.18 \\
\hline LOI & 0.7 & 1.5 & 1.5 & 0.8 & 0.5 & 1 & 0.8 & 2.5 & 0.6 & 0.4 & 1.07 \\
\hline Total & 99.921 & 100.07 & 99.89 & 100.01 & 100 & 99.89 & 99.82 & 99.86 & 99.97 & 99.89 & 99.7999 .92 \\
\hline $\mathrm{Ba}$ & 56 & 115 & 39 & 89 & 9 & 1.3 & 22 & 62 & 40 & 40 & 7450.82 \\
\hline $\mathrm{Ni}$ & 14.6 & 6.6 & 6.5 & 14.2 & 16.9 & 10.4 & 11.1 & 10 & 13.1 & 12.3 & 510.97 \\
\hline
\end{tabular}

* Duplicate analysis 


\section{Table 1 (Continued)}

\begin{tabular}{|c|c|c|c|c|c|c|c|c|c|c|c|c|}
\hline $\begin{array}{l}\text { Oxide/ } \\
\text { Element }\end{array}$ & Rl & R49 & R50 & R51 & R52 & R53 & R54 & R55 & R56 & R56* & R.57 & MEAN \\
\hline $\mathrm{Cu}$ & 8.55 & 14.4 & 21.4 & 21.1 & 7.59 & 36.4 & 36.7 & 36.5 & 7.5 & 7.49 & 3.98 & 18.3 \\
\hline $\mathrm{Ga}$ & 2.1 & 2.8 & 3.5 & 3.5 & 2 & 2.2 & 2.4 & 4 & 1.7 & 1.8 & 1.2 & 2.47 \\
\hline Hf & 0.2 & 0.3 & 0.4 & 0.3 & 0.1 & 0.2 & 0.2 & 0.3 & 0.1 & 0.1 & 0.1 & 0.21 \\
\hline $\mathrm{Nb}$ & 0.55 & 0.37 & 0.67 & 0.58 & 0.51 & 0.42 & 0.48 & 0.61 & 0.31 & 0.34 & 0.26 & $0.4 t$ \\
\hline $\mathrm{Rb}$ & 18.58 & 21.19 & 1.67 & 30.86 & 0.97 & 0.97 & 1.32 & 1.02 & 0.61 & 0.53 & 13.98 & 8.34 \\
\hline $\mathrm{Sr}$ & 74.3 & 29.5 & 6.3 & 106 & 4.1 & 4 & 4.8 & 88.1 & 13.7 & 14 & 20.7 & 33.23 \\
\hline Th & 0.6 & 0.5 & 0.8 & 0.6 & 0.5 & 0.3 & 0.2 & 0.6 & 0.6 & 0.6 & 0.2 & 0.50 \\
\hline U & 2.2 & 0.2 & 0.6 & 0.3 & 7 & 0.5 & 0.6 & 1.5 & 0.6 & 0.6 & 0.1 & 1.29 \\
\hline $\mathrm{Zr}$ & 8.2 & 12.4 & 18.2 & 15.2 & 6.4 & 8.1 & 8.9 & 11.7 & 5.9 & 6.2 & 5.5 & 9.70 \\
\hline Y & 2.5 & 2.2 & 3.8 & 4.8 & 1.3 & 2.7 & 2.4 & 7.8 & 2 & 2.1 & 2.8 & 3.13 \\
\hline $\mathrm{La}$ & 19 & 6.3 & 6.2 & 3.5 & 2.8 & 4.1 & 6.6 & 21.9 & 16 & 15.9 & 2.4 & 9.52 \\
\hline $\mathrm{Ce}$ & 11 & 6.9 & 9.6 & 6.4 & 3.8 & 5.5 & 8.8 & 38.8 & 23.8 & 24.3 & 2.8 & 12.88 \\
\hline $\operatorname{Pr}$ & 2.28 & 0.76 & 1.35 & 0.71 & 0.54 & 0.77 & 0.99 & 7.37 & 2.89 & 2.91 & 0.52 & 1.92 \\
\hline $\mathrm{Nd}$ & 6.7 & 2.7 & 5.5 & 3.4 & 2 & 2.9 & 3.3 & 37.3 & 10.2 & 9.3 & 2.1 & 7.76 \\
\hline $\mathrm{Sm}$ & 0.9 & 0.4 & 1 & 0.6 & 0.4 & 0.6 & 0.5 & 7.4 & 1 & 1.1 & 0.4 & 1.30 \\
\hline Eu & 0.3 & 0.18 & 0.32 & 0.37 & 0.12 & 0.28 & 0.24 & 1.67 & 0.36 & 0.36 & 0.2 & 0.40 \\
\hline $\mathrm{Gd}$ & 0.85 & 0.39 & 0.85 & 0.73 & 0.3 & 0.59 & 0.56 & 3.98 & 0.97 & 0.94 & 0.38 & 0.96 \\
\hline $\mathrm{Tb}$ & 0.1 & $<0.05$ & 0.11 & 0.11 & $<0.05$ & 0.07 & 0.07 & 0.38 & 0.08 & 0.08 & $<0.05$ & 0.13 \\
\hline Dy & 0.49 & 0.27 & 0.72 & 0.58 & 0.24 & 0.56 & 0.47 & 1.72 & 0.46 & 0.38 & 0.38 & 0.57 \\
\hline Ho & 0.09 & 0.06 & 0.13 & 0.13 & $<.05$ & 0.1 & 0.08 & 0.29 & 0.07 & 0.06 & 0.08 & 0.11 \\
\hline $\mathrm{Er}$ & 0.25 & 0.2 & 0.37 & 0.42 & 0.14 & 0.29 & 0.23 & 0.83 & 0.2 & 0.19 & 0.25 & 0.31 \\
\hline $\mathrm{Tm}$ & $<0.05$ & $<0.05$ & 0.06 & $<0.05$ & $<0.05$ & $<0.05$ & $<0.05$ & 0.1 & $<0.05<$ & 60.05 & $<0.05$ & 0.08 \\
\hline$Y b$ & 0.22 & 0.2 & 0.38 & 0.37 & 0.13 & 0.31 & 0.24 & 0.57 & 0.17 & 0.18 & 0.23 & 0.27 \\
\hline Lu & 0.04 & 0.04 & 0.06 & 0.04 & 0.02 & 0.05 & 0.04 & 0.09 & 0.03 & 0.03 & 0.04 & 0.04 \\
\hline As & 1.2 & 3.6 & 7 & 3.9 & 7.5 & 4.5 & 5.8 & 2.3 & 2.4 & 2.4 & 4.4 & 4.09 \\
\hline Sb & 0.4 & 2.13 & 1.94 & 2.07 & 1.13 & 2.37 & 1.75 & 1.51 & 0.43 & 0.43 & 0.35 & 1.32 \\
\hline V & 5 & 14 & 16 & 11 & 14 & 10 & 8 & 39 & 7 & 7 & & 12.09 \\
\hline $\mathrm{Zn}$ & 6.2 & 23.9 & 6.3 & 35.6 & 2.4 & 3.8 & 4.2 & 38.1 & 4 & 3.7 & 5.2 & 12.13 \\
\hline $\mathrm{Co}$ & 1.3 & 1.9 & 1.9 & 3.9 & 2.2 & 2.5 & 1.5 & 2.9 & 2.5 & 2.3 & 1 & 2.17 \\
\hline $\begin{array}{l}\text { Total } \\
\text { REE }\end{array}$ & 42.22 & 18.4 & 26.65 & 17.36 & 10.49 & 16.12 & 22.12 & 122.4 & 56.23 & 55.73 & 9.78 & 36.14 \\
\hline $\mathrm{Fe} / \mathrm{Ti}$ & 187.2 & 276.0 & 161.8 & 215.0 & 354.4 & 425.0 & 687.3 & 383.3 & 753.7 & 760.81 & 1024.0 & 475.3 \\
\hline $\begin{array}{l}\mathrm{Al} / \mathrm{Al}+\mathrm{Fe} \\
+\mathrm{Mn}\end{array}$ & 0.092 & 0.032 & 0.049 & 0.042 & 0.038 & 0.030 & 0.014 & 0.022 & 0.014 & 0.014 & 0.013 & 0.033 \\
\hline $\mathrm{Zr} / \mathrm{Hf}$ & 41.0 & 41.3 & 45.5 & 50.7 & 64.0 & 40.5 & 44.5 & 39.0 & 59.0 & 62.0 & 55.0 & 49.3 \\
\hline $\begin{array}{l}\mathrm{Co}+\mathrm{Cu}+ \\
\mathrm{Ni}\end{array}$ & 24.5 & 22.9 & 29.8 & 39.2 & 26.69 & 49.3 & 49.3 & 49.4 & 23.1 & 22.1 & 9.98 & 31.50 \\
\hline $\mathrm{Y} / \mathrm{P}_{2} \mathrm{O}_{5}$ & 50.0 & 20.0 & 21.1 & 32.0 & 65.0 & 45.0 & 24.0 & 39.0 & 50.0 & 19.1 & 15.6 & 34.6 \\
\hline
\end{tabular}

* Duplicate analysis

When compared to post-Archaean average upper continental crust (Taylor and McLennan 1981), the BIF are strongly depleted in the transition metals ( $\mathrm{Sc}$ and $\mathrm{V}$ ), REE, High Field Strength Elements ( $\mathrm{Nb}, \mathrm{U}, \mathrm{Th}, \mathrm{Zr}, \mathrm{Hf}, \mathrm{Pb}$ ), 
Large Ion Lithophile Elements $(\mathrm{Ba}, \mathrm{Sr}, \mathrm{Rb})$ and $\mathrm{Y}$. The mean trace element composition of the BIF (Table 1) is plotted in a Primitive Mantle normalised (Normalising values after McDonough and Sun 1995) spidergram in Figure 2. Apart from overall lower abundances and more pronounced negative anomalies for $\mathrm{Nb}, \mathrm{Sr}$, Hf and $\mathrm{Ti}$, the average BIF shows a pattern that is very similar to that of the average upper crust. The only notable differences between average upper crust and the BIF is the strong enrichment of $U$ relative to $T h$ and $K$ in the latter. The BIF pattern is also characterised by positive $\mathrm{Nd}-\mathrm{P}$ and negative $\mathrm{Hf}$ and $\mathrm{Zr}$ anomalies which features are absent in the upper continental crust (Fig. 2). Nd is, however, not correlated with $\mathrm{P}_{2} \mathrm{O}_{5}$ indicating little influence of sedimentary apatite in the REE budget of the BIF.

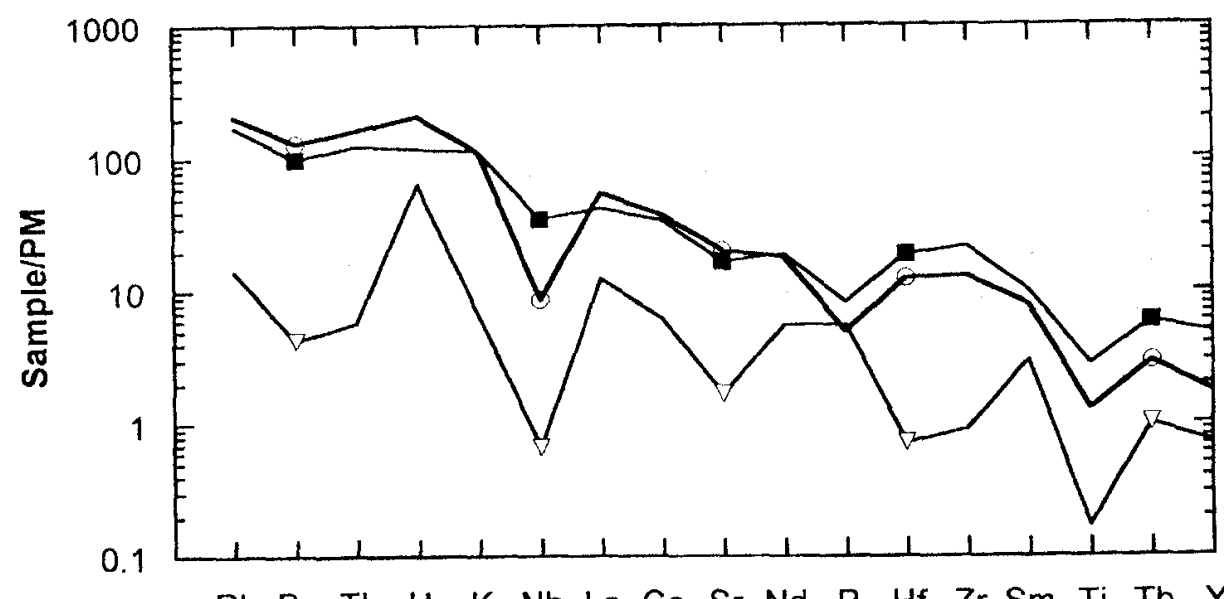

Fig. 2: Primitive Mantle (PM) normalised diagrams indicating the trace element geochemical similarity between the average Geita BIF (open triangles), average upper continental crust (solid squares) and average Geita granite (open circles). The upper crust data are from Taylor and McLennan (1981) whereas the granite data are from Maboko and Manya (unpublished data). Normalizing values are from Macdough and Sun (1995)

Figure 3 shows shale-normalised REE patterns for the BIF samples. The samples are depleted by up to an order of magnitude in the REE relative to average North American Shale (Gromet et al. 1984) and show nearly flat patterns which are characterised by small positive Eu anomalies and very slight negative Ce anomalies (Fig. 3). These patterns are in marked contrast to the heavy $(H)$ REE-enriched patterns of modern sea water (Sholkovitz \& 
Szymczak 2000) and most other Precambrian iron formations (Bau and Moller 1993).

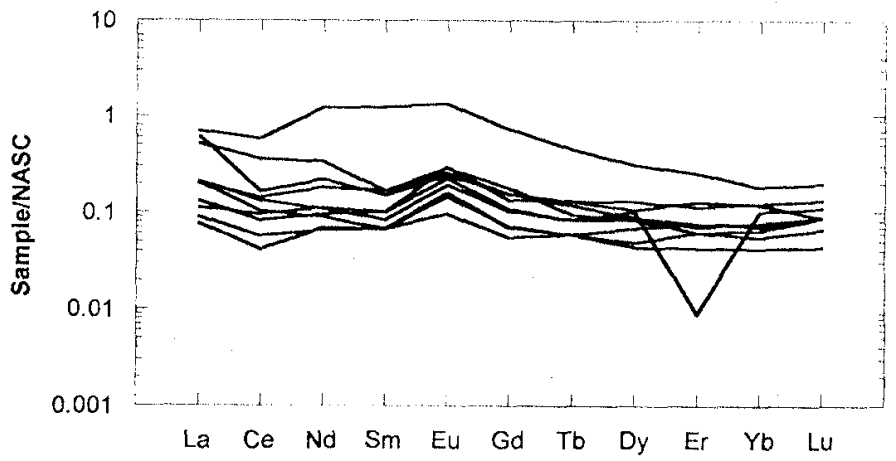

Fig. 3: North American Shale (NASC) normalised REE patterns for the Geita BIF. The normalizing values are from Gromet et al. (1984)

The REE data are plotted in chondrite normalised (Normalising values after Boynton 1984) diagrams in Figure 4. All samples are characterised by light (L) REE-enriched $\left((\mathrm{La} / \mathrm{Yb})_{\mathrm{N}}=7-60\right.$ : the subscript $\mathrm{N}$ indicates chondrite normalised values) and nearly flat to slightly depleted HREE $\left((\mathrm{Tb} / \mathrm{Yb})_{\mathrm{N}}=0.95\right.$ -2.9) patterns on which are superposed slightly positive Eu anomalies and very small negative $\mathrm{Ce}$ anomalies (Fig. 4). These patterns differ from the HREE-enriched trends $\left((\mathrm{Sm} / \mathrm{Yb})_{\mathrm{N}}<1\right)$ which characterise most Archaean BIF (see for example Bau and Moller 1993). Apart from the positive Eu anomalies, however, the Geita BIF patterns are similar to the REE patterns of pelagic clays (Barrett 1981).

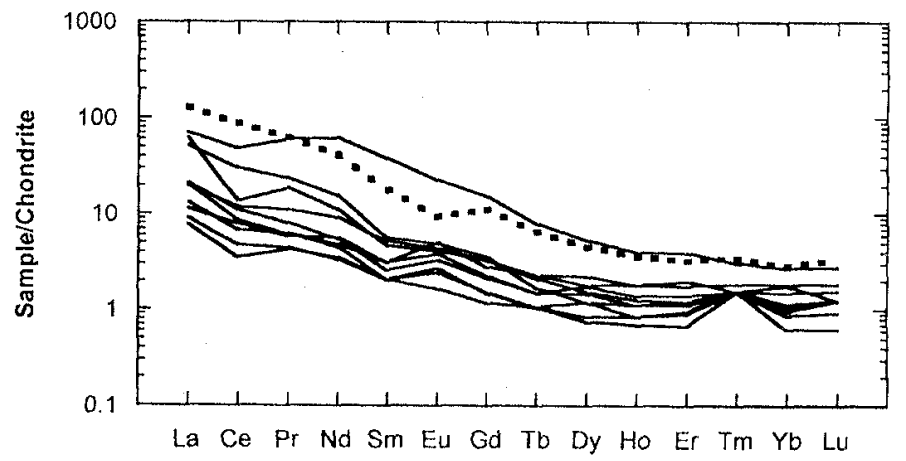

Fig. 4: Chondrite normalised REE patterns for the Geita BIF. The heavy dotted line indicates the pattern for average Geita granite and is from Maboko and Manya (unpublished data). Normalizing values are from Boynton (1984) 


\section{DISCUSSION \\ Origin of the BIF}

Metalliferous sediments, including BIF, can form as a result of hydrothermal precipitation from seawater, diagenetic processes or physical accumulation of metal-rich detritus. Bonatti (1975) suggested that hydrothermal metal-rich deposits could be distinguished from hydrogenous deposits formed by diagenetic processes on the basis of the relative abundances of $\mathrm{SiO}_{2}$ and $\mathrm{Al}_{2} \mathrm{O}_{3}$. On a plot of $\mathrm{SiO}_{2}$ versus $\mathrm{Al}_{2} \mathrm{O}_{3}$, all the Geita $\mathrm{BIF}$ samples plot in the field of hydrothermal deposits suggesting that they are chemical precipitates with little or no detrital input (Fig. 5). The relative proportion of detrital, if any, to hydrothermal input in such deposits can be inferred using Fe-Ti-Mn-Al systematics (Bostrom 1973, Barret 1981, Wonder et al. 1988). Pure hydrothermal deposits contain very little $\mathrm{Al}$ and have high Fe/Ti ratios (Bostrom 1973, Marchig et al. 1982). Contamination of such deposits by pelagic and terrigenous deep-sea sediments enriches them in components such as $\mathrm{Ti}$ and $\mathrm{Al}$ resulting in a drastic lowering of the Fe/Ti ratio and an increase in the $\mathrm{Al} /(\mathrm{Al}+\mathrm{Fe}+\mathrm{Mn})$ ratio. On an $\mathrm{Fe} / \mathrm{Ti}$ versus $\mathrm{Al} /(\mathrm{Al}+\mathrm{Fe}+\mathrm{Mn})$ diagram (Bostrom 1973, Barret 1981, Wonder et al. 1988), the Geita samples cluster on or close to the hydrothermal end of a mixing curve between hydrothermal deposits, as represented by the metal-rich sediments of the East Pacific Rise, and pelagic sediments (Fig. 6). This suggests that the major elements in the BIF are predominantly $(\geq \sim 80 \%)$ of hydrothermal origin. A predominantly hydrothermal origin is also consistent with the low $\mathrm{Y}_{2} \mathrm{P}_{2} \mathrm{O}_{5}$ ratios which fall in the $15-65$ range (mean $=36 \pm 10,2 \mathrm{SE}$ ), similar to ratios expected in pure hydrothermal deposits but lower than ratios of $>100$ found in pelagic and hydrogenous deposits (Marchig et al. 1982). The major and trace element data, therefore, suggest that the Geita BIF, like most other Archaean and Proterozoic iron formations, were deposited from hydrothermal solutions. 


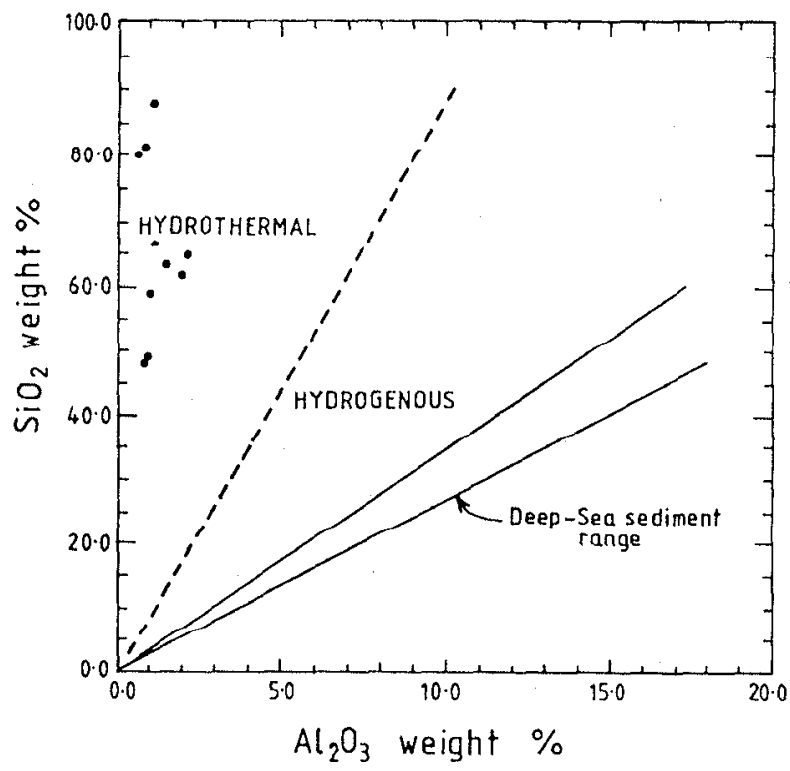

Fig. 5: $\mathrm{SiO}_{2}$ versus $\mathrm{Al}_{2} \mathrm{O}_{3}$ discrimination diagram (after Bonatti 1975) for the Geita BIF indicating their hydrothermal affinity. Also indicated are fields for hydrogenous deposits and deep-sea sediments

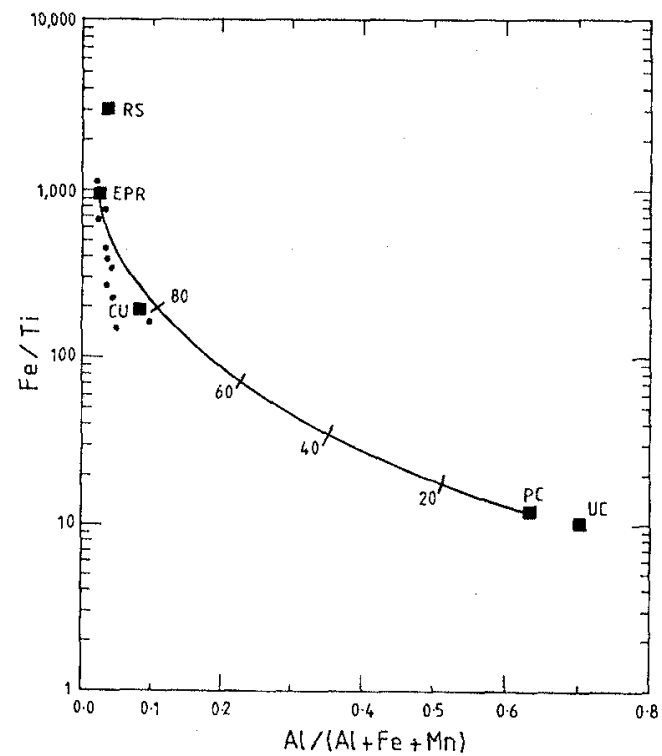

Fig. 6: Fe/Ti versus $\mathrm{Al} /(\mathrm{Al}+\mathrm{Fe}+\mathrm{Mn})$ systematics for the Geita BIF. The curve represents mixing of East Pacific Rise hydrothermal deposits (EPR) with pelagic sediments (PC) whereas the numbers indicate the approximate percentage of EPR in the mixture (adopted from Barret 1981). Also indicated are compositions for mean upper continental crust (UC, Taylor and McLennan 1981), Red Sea hydrothermal deposits (RS, Marchig et al. 1982) and the Cyprus umbc. (CU, Bostrom 1973) 


\section{Sources of the chemical components}

Trace elements, and REE in particular, have been successfully used to put constraints on the relative importance of terrigenous and volcanogenic components in BIF and other Fe-rich sediments (Dymek \& Klein 1988, Manikyamba \& Naqvi 1995, Lottermoser \& Ashley 2000). While variable, the REE patterns of BIF from different parts of the world share some important similarities. Most of them show patterns characterised by HREE enrichment $\left((\mathrm{Sm} / \mathrm{Yb})_{\mathrm{N}}<1\right),(\mathrm{La} / \mathrm{Nd})_{\mathrm{N}}>1$ and positive Eu anomalies. These characteristics are also shared by modern deep-sea metalliferous sediments found on midocean ridge flanks (Ruhlin \& Owen 1986) and have been interpreted as indicating precipitation of BIF from multi-component systems consisting of variable mixtures of hydrothermal fluids containing REE leached from the basalts of the sea floor and surface marine waters, the REE signature of which resemble modern sea water (Jacobsen \& Pimentel-Klose 1988, Derry \& Jacobsen 1990, Bau \& Moller 1993, Bau \& Dulski 1996). Thus, the positive $\mathrm{Eu}$ anomalies are generally interpreted as reflecting the hydrothermal component whereas the HREE-enrichment reflects the influence of surface marine waters (Derry \& Jacobsen 1990, Bau \& Moller 1993). Similar to other Precambrian BIF, the Geita samples are characterised by slightly positive Eu anomalies $\left(\left(\mathrm{Eu} / \mathrm{Eu}^{*}=1.3-2.0\right.\right.$, mean $\left.=1.6\right)$ and $(\mathrm{La} / \mathrm{Nd})_{\mathrm{N}}>1(1.1-5.5$, mean $=3.0$ ) which features reflect the hydrothermal influence. In contrast to most other BIF, however, the Geita samples show strong HREE depletion $\left((\mathrm{Sm} / \mathrm{Yb})_{\mathrm{N}}=1.9-6.6\right.$, mean $\left.=4.1\right)$. The HREE-depleted patterns of the BIF can not be explained by precipitation from a mixture of hydrothermal solutions similar to those found along modern mid-oceanic ridges or back-arc spreading centres and modern marine surface waters. Modern hydrothermal solutions are characterised by low REE abundances (pg/g levels) and patterns with large positive Eu anomalies, LREE enrichment and nearly flat to depleted HREE (Michard et al. 1984, Fouquet et al. 1993). On the other hand, modern seawater is dominated by REE from the dissolved fraction carried into the ocean by rivers. This fraction is usually characterised by HREE-enriched patterns due to fractionation processes occurring in the estuarine environment which preferentially scavenge the LREE relative to the HREE (Bau \& Moller 1993, Sholkovitz \& Szymczak 2000). The REE patterns of most BIF can be explained by precipitation from hydrothermal solutions that have been strongly diluted by seawater (Dymek \& Klein 1988, Derry \& Jacobsen 1990, Bau \& Moller 1993). The seawater imparts the strong HREE enrichment (Dymek \& Klein 1988) whereas the hydrothermal component is reflected in the positive Eu anomalies and the LREE enrichment. Depletion in the HREE in chemical sediments, as reflected in elevated $(\mathrm{Sm} / \mathrm{Yb})_{\mathrm{N}}$ ratios have been attributed to an increased contribution of particulate and colloidal components in the total REE budget (Bau \& Moller 1993). The HREE-depletion in the Geita samples is similarly interpreted as indicating a detrital influence on their trace element geochemistry. A comparison of the REE patterns of samples with differing degrees of detrital contamination, as measured by different $\mathrm{Fe} / \mathrm{Ti}$ ratios, suggests that an increase in the detrital component results in 
higher relative abundances of the light and middle REE (Fig. 7). A detrital influence on the trace element geochemistry of the BIF is also supported by ratios of the High Field Strength Elements $\mathrm{Zr}$ and $\mathrm{Hf}$ whereby the BIF have $\mathrm{Zr} / \mathrm{Hf}$ ratios $(41-64$, mean $48 \pm 5,2 \mathrm{SE}$ ) which are similar to the crustal average of $\sim 40$ (Dymek \& Klein 1988). A positive correlation between $\mathrm{Al}_{2} \mathrm{O}_{3}$, a known indicator of detrital contamination in chemical sediments, with some trace elements ( $\mathrm{Ti}, \mathrm{Ga}, \mathrm{Hf}, \mathrm{Rb}, \mathrm{Th}$ and $\mathrm{Zr}$ ) provides further evidence for a terrigenous influence on these $\mathrm{BIF}$ geochemistry. $\mathrm{SiO}_{2}$ and $\mathrm{Fe}_{2} \mathrm{O}_{3}$, however, show no correlation with the trace elements possibly because the $\mathrm{SiO}_{2}$ and $\mathrm{Fe}_{2} \mathrm{O}_{3}$ are of mixed hydrothermal and detrital parentage.

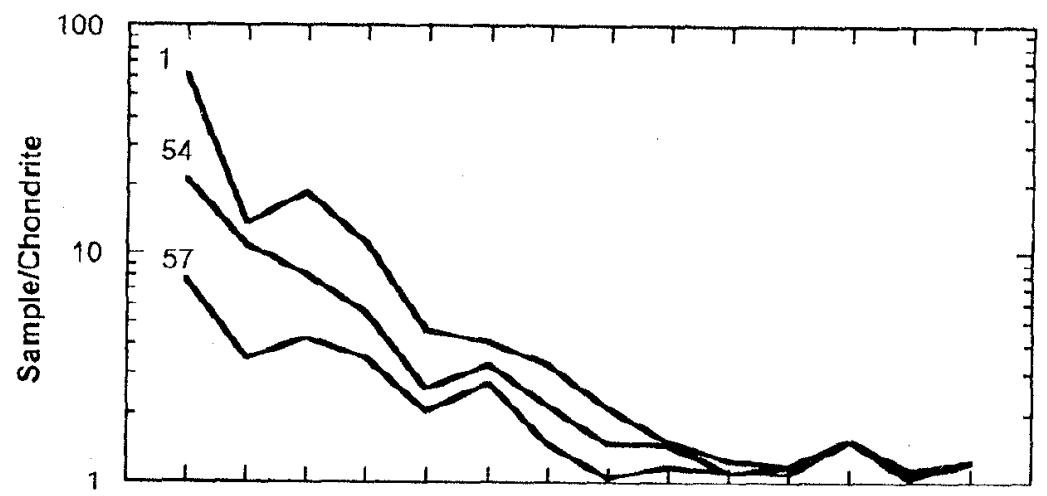

La Ce Pr Nd Sm Eu Gd Tb Dy Ho Er Tm Yb Lu

Fig. 7: Chondrite normalised REE patterns for samples with different degrees of detrital contamination as measured by different Fe/Ti ratios (187.2 for sample R1, 687.3 for sample R54 and 1024.0 for sample R57). Note the enrichment in the light and middle REE as the detrital component increases

Major rock types exposed in and around the Sukumatand Greenstone Belt that could potentially contribute detritus to the BIF depository during Neoarchaean time include metabasalts, felsic volcanics and granites. The crustal-like $\mathrm{Zr} / \mathrm{Hf}$ ratios observed in the BIF, together with the lack of enrichment in $\mathrm{Ni}$, Co and $\mathrm{Sc}$ relative to average shale preclude a significant contribution of detritus from the metabasalts (Manikyamba \& Naqvi 1995). This is also consistent with the fact that the BIF have a mean ${ }^{147} \mathrm{Sm} /{ }^{144} \mathrm{Nd}$ ratio of $0.10 \pm 0.01$ ( $2 \mathrm{SE}$ ), indistinguishable from the $\sim 0.11$ mean value of detritus produced by the weathering of typical upper continental crustal rocks (Jacobsen \& Pimentel-Klose 1988). Weathering of predominantly mafic volcanic rocks would result in significantly higher ${ }^{147} \mathrm{Sm} /{ }^{144} \mathrm{Nd}$ ratios of $\sim 0.15$ (Jacobsen \& Pimentel-Klose 1988). Instead, the BIF show trace element characteristics that closely resemble those of typical Archaean granites, similar to those intruding the Nyanzian succession in the Sukumaland Greenstone Belt. This similarity, which is revealed by the parallelism of the REE and primitive mantle-normalised patterns of the BIF and granites (Figs. 2 and 4), suggests that the trace elements in the BIF were derived from detritus with 
geochemical characteristics similar to that of the granites. As the granites in the Nyanzian clearly post-date BIF deposition, it is suggested that the felsic flows and pyroclastics which preceded the granitic magmatism supplied the sediments. This interpretation is supported by the presence of numerous tuffaceous horizons in the BIF (Walraven et al. 1994) and the fact that a trachyandesite sample interbedded with the BIF has an REE pattern that is very similar to that of both the granites and the BIF (Fig. 8). Since even samples like R57, which show minimal contamination by detrital material as revealed by their high Fe/Ti ratios (Table 1), also show HREE-depleted patterns (Fig. 7), it is proposed that some of the REE might have been derived from the hydrothermal leaching of the felsic volcanics and pyroclastics. The interbedding of the iron formations with volcanic flows provides evidence of active volcanism during the BIF deposition that could have facilitated hydrothermal leaching. $\mathrm{Al}_{2} \mathrm{O}_{3}$ is considered relatively immobile during hydrothermal leaching (Mottl \& Holland 1978, Seyfried \& Bischoff 1981). Thus, derivation of some of the REE by hydrothermal leaching could also explain the de-coupling of $\mathrm{Al}_{2} \mathrm{O}_{3}$ and the REE as indicated by the lack of correlation between $\mathrm{Al}_{2} \mathrm{O}_{3}$ and the total REE. The leached fraction would only contribute the REE and other trace elements to the hydrothermal solutions but $\operatorname{not} \mathrm{Al}_{2} \mathrm{O}_{3}$.

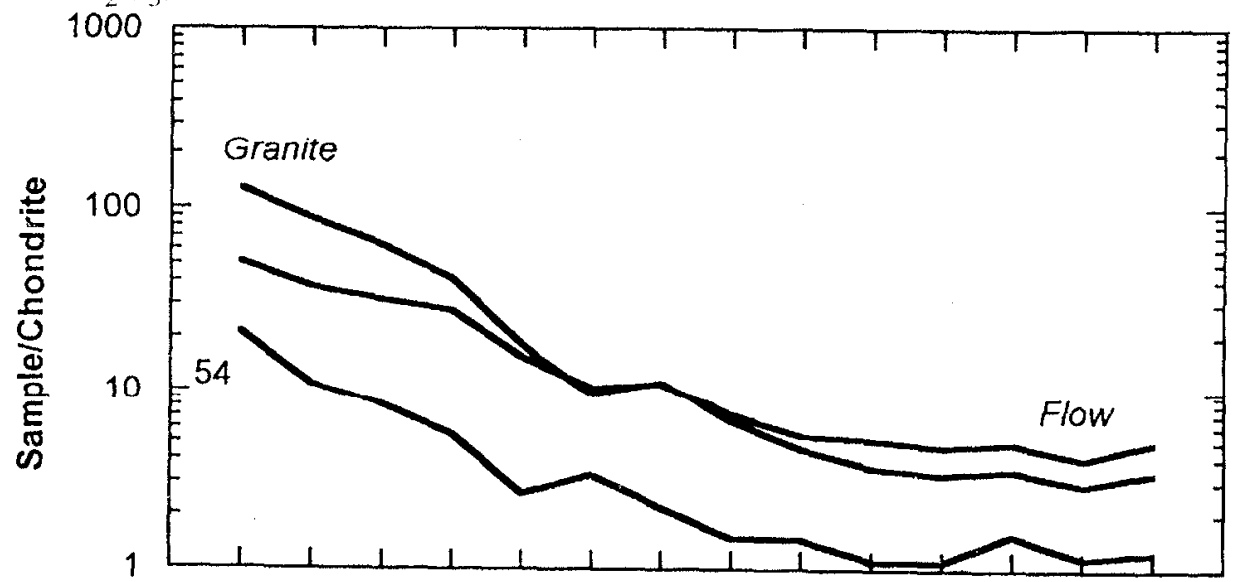

La Ce Pr No Sm Eu Gd Tb Dy Ho Er Tm Yb Lu

Fig. 8: Comparison of the chondrite normalised patterns for average Geita granite, least contaminated BIF (R54) and trachyandesite flow interbedded with the BIF. Even the uncontaminated BIF sample shows an REE pattern that parallels the patterns for granite and trachyandesite

\section{CONCLUSION}

The Geita BIF were precipitated from hydrothermal solutions with a maximum contamination by detrital material of $\sim 20 \%$ by weight. The BIF are characterised by crustal-like $\mathrm{Zr} / \mathrm{Hf}$ and ${ }^{144} \mathrm{Sm} /{ }^{144} \mathrm{Nd}$ ratios and REE patterns which, apart from positive Eu anomalies, are similar to those of typical 
Archaean granites. This shows that, despite their lower proportions, granitic detritus probably derived from contemporaneous felsic flows and pyroclastics provided the dominant trace element geochemical characteristics of the BIF. However, even apparently detritus-free samples show the crustal geochemical signature suggesting that some of the chemical elements were derived from the hydrothermal leaching of the interbedded felsic volcanics and pyroclastics.

\section{ACKNOWLEDGEMENT}

This work was funded by Sida/SAREC through the Research Capacity Development in the Faculty of Science Project (Geochemical Mapping in the Lake Victoria Gold Fields sub-project). Shukrani Manya provided invaluable technical assistance.

\section{REFERENCES}

Ashley PM, Lottermoser BG and Westaway JM 1998 Iron formations and epigenetic ironstones in the Palaeoproterozoic Willyama Supergroup, Olary Domain, South Australia. Mineralogy and Petrology 64: 187-218

Barley ME, Pickard AL, Sylvester PJ 1997 Emplacement of a large igneous province as a possible cause of banded iron formation $2.45 \mathrm{Ma}$ ago. Nature 385: 55-58

Barrett TJ 1981 Chemistry and mineralogy of Jurassic bedded chert overlying ophiolites in the north Appenines, Italy. Chemical Geology 34: 289-317

Barth H 1990 Provisional Geological Map of the Lake Victoria Gold Fields, Tanzania 1: 500000 (with explanatory notes). Geologisches Jahrbuch B72: 3-59

Bau M and Dulski P 1996 Distribution of ytrrium and rare earth elements in the Penge and Kuruman iron formations, Transvaal Supergroup, South Africa. Precambrian Research 79: 37-55

Bau M and Moller P 1993 Rare earth element systematics of the chemically precipitated iron formations and the evolution of the terrestrial atmosphere-hydrosphere-lithosphere system. Geochimica et Cosmochimica Acta 57: 2239-2249

Bonatti E 1975 Metallogenesis at oceanic spreading centres. Annual Review of Earth and Planetary Sciences 3: 401-433

Borg G 1992 New aspects on the lithostratigraphy and evolution of the Siga Hills, an Archaean granite-greenstone terrain in NW Tanzania. Zeitschrift fur Angewand:- Geologie 38: 89-93

Borg $\mathrm{S}$ and Krogh T 1999 Isotopic age data of single zircons from the Archaean Sukunidind Greenstone Belt, Tanzania. Journal of African Earth Sciences 29: 301-312

Borg S and Shackleton RM 1997 The Tanzania and NE Zaire Cratons. In: de Wit MJ and Ashwal LD (eds). Greenstone Belts Clarendon Press, Oxford 
Bostrom K 1973 The origin and fate of ferromanganoan active ridge sediments. Stockholm Contributions to Geology 27: 149-243

Boynton WV 1984 Cosmochemistry of the rare earth elements: Meteorite studies. In: Henderson P (ed) Rare earth element geochemistry Elsevier, Amsterdam

Derry LA and Jacobsen SB 1990 The chemical evolution of Precambrian seawater: Evidence from REEs in banded iron formations. Geochimica et Cosmochimica Acta 54: 2965-2977

Dymek RF and Klein C 1988 Chemistry, petrology and origin of banded iron formation lithologies from the 3800 Ma Isua supracrustal belt, West Greenland. Precambrian Research 39: 247-302

Fouquet Y, von Stackelberg U, Charlou JL, Erzinger J, Herzig PM, Muhe R and Wiedicke M 1993 Metallogenesis in back-arc environments: The Lau Basin example. Economic Geology 88: 2154-2181

Garrels RM 1987 A model for the deposition of the microbanded Precambrian iron formations. American Journal of Science 287 : $81-106$

Goodwin AM 1962 Structure, stratigraphy and origin of iron formations, Michipicoten Area, Algoma District, Ontario, Canada. Geological Society of America Bulletin 73: 561-586

Grantham DR, Temperley BN and McConnell RB 1945 Explanation of the geolgy of degree sheet No.17. Kahama. Bulletin of the Geological Survey Tanganyika (Dar es Salaam) 39 pp

Gromet LP, Dymek RF, Haskin LA and Korotev RL 1984 The "North American shale composite": its compilation, major and trace element characteristics. Geochimica et Cosmochimica Acta 48: 2469-2482

Halbich IW, Scheepers R, Lamprecht D, van Deventer JN and de Kock NJ 1993 The Transvaal-Griqualand West banded iron formation: geology, genesis, iron exploitation. Journal of African Earth Sciences 16:63-120

Holland HD 1984 The Chemical Evolution of the Atmosphere and Oceans. Princeton University Press

Jacobsen SB and Pimentel-Klose MR 1988 A Nd isotopic study of the Hamersley and Michipicoten banded iron formations: the source of REE and Fe in Archaean oceans. Earth and Planetary Science Letters 87: 29-44

James HL 1954 Sedimentary facies of iron formation. Economic Geology 49: 235-291

Klemm DD 2000 The formation of Palaeoproterozoic banded iron formations and their associated $\mathrm{Fe}$ and $\mathrm{Mn}$ deposits, with reference to the Griqualand West deposits, South Africa. Journal of African Earth Sciences 30: 1-24

Lepp H and Goldich SS 1973 Origin of Precambrian iron formations. Economic Geology 59: 1025-1060 
Lottermoser BG and Ashley PM 2000 Geochemistry, petrology and origin of Neoproterozoic ironstones in the eastern part of the Adelaide Geosyncline, South Australia. Precambrian Research 101: 49-67

Manikyamba C and Naqvi SM 1995 Geochemistry of Fe-Mn formations in the Archaean Sandur schist belt, India - mixing of clastic and chemical processes at a shallow shelf. Precambrian Research 72: 69-95

Marchig V, Gundlach H, Moller P and Schley F 1982 Some geochemical indicators for discrimination between diagenetic and hydrothermal metalliferous sediments. Marine Geology 50: 241-256

McDonough WF and Sun S-s 1995 The composition of the Earth. Chemical Geology 120: 223-253

Michard G, Albarede F, Michard A, Minster JF, Charlou JL and Tan N 1984 Chemistry of solutions from $13 \%$ N East Pacific Rise hydrothermal site. Earth and Planetary Science Letters 67: 297307

Mottl MJ and Holland HD 1978 Chemical exchange during hydrothermal alteration of basalt by seawater-I: Experimental results for major and minor components of seawater. Geochemica et Cosmochimica Acta 42: 1103-1115

Ruhlin DE and Owen RM 1986 The rare earth element geochemistry of hydrothermal sediments from the East Pacific Rise: Examination of a seawater scavenging mechanism. Geochemica et Cosmochimica Acta 50: 393-400

Seyfried WE Jr. and Bischoff JL 1981 Experimental seawater-basalt interaction at $300 \% 0 \mathrm{C}, 500$ bars: chemical exchange, secondary mineral formation and implication for transport of heavy metals. Geochemica et Cosmochimica Acta 45: 135-147

Sholkovitz E and Szymczak R 2000 The estuarine chemistry of rare earth elements: comparison of the Amazon, Fly, Sepik and the Gulf of Papua systems. Earth and Planetary Science Letters 179: 299309

Taylor SR and McLennan SM 1981 The composition and evolution of the continental crust: rare earth element evidence from sedimentary rocks. Philosophical Transactions of the Royal Society of London A301: 381-399

Walraven F, Pape J and Borg G 1994 Implications of Pb-isotopic compositions at the Geita gold deposit, Sukumaland Greenstone Belt, Tanzania. Journal of African Earth Sciences 18: 111-212

Wonder JD, Spry PG and Windom KE 1988 Geochemistry of manganeserich rocks related to iron formation and sulphide deposits, Western Georgia. Economic Geology 83: 1070-1081 